\begin{tabular}{|l|l|l|}
\hline \multicolumn{2}{|c|}{ PublisherInfo } \\
\hline \hline PublisherName & $:$ & BioMed Central \\
\hline \hline PublisherLocation & $:$ & London \\
\hline \hline PublisherImprintName & $:$ & BioMed Central \\
\hline \hline
\end{tabular}

\title{
A T cell receptor transgenic mouse model of inflammatory
} arthritis

\begin{tabular}{|l|l|l||}
\hline \multicolumn{2}{|c||}{ ArticleInfo } \\
\hline \hline ArticleID & $:$ & 247 \\
\hline \hline ArticleDOI & $:$ & $10.1186 /$ ar-1999-66724 \\
\hline \hline ArticleCitationID & $:$ & 66724 \\
\hline \hline ArticleSequenceNumber & $:$ & 204 \\
\hline \hline ArticleCategory & $:$ & Paper Report \\
\hline ArticleFirstPage & $:$ & 1 \\
\hline \hline ArticleLastPage & $:$ & 4 \\
\hline \hline & & RegistrationDate : 1999-8-20 \\
\hline ArticleHistory & $:$ & OnlineDate \\
\hline \hline ArticleCopyright & $:$ & Current Science Ltd1999-8-20 \\
\hline \hline ArticleGrants & $:$ & \\
\hline \hline ArticleContext & $:$ & 130753311 \\
\hline \hline
\end{tabular}


Andrew Cope, ${ }^{\text {Aff1 }}$

Aff1 Kennedy Institute of Rheumatology, London, UK

\section{Keywords}

Autoimmunity, immunoglobulins, rheumatoid arthritis, T cell receptor, transgenic mouse

\section{Context}

The use of animal models of arthritis has profoundly influenced our understanding of the pathogenic mechanisms thought to contribute to the development of rheumatoid arthritis in man. However, progress has been hampered to some extent by the lack of a robust and reproducible spontaneous arthritis model. In 1996, the laboratory of Mathis and Benoist reported a detailed characterisation of a T cell receptor (TCR) transgenic mouse that developed a spontaneous chronic inflammatory arthritis with many of the histological features of human rheumatoid arthritis (RA). The key feature of this model was the development of systemic T cell reactivity to self-peptide/self-MHC class II complexes. Cross-reactive recognition was achieved by introducing rearranged TCR alpha and beta chains (the KRN receptor), specific for a bovine ribonuclease peptide, presented by I-Ak onto the NOD background, which carries the murine MHC class II alleles encoding I-Ag7. The presence of both the KRN receptor and I-Ag7 was critical for the development of arthritis, and occurred with $100 \%$ penetrance. This was despite multiple levels of tolerance induction, manifest by efficient thymic clonal deletion for the first three weeks of life, downregulation of the KRN TCR because of upregulation of endogenous TCR chains and incomplete allelic exclusion, and lower than expected numbers of peripheral $\mathrm{CD} 4{ }^{+} \mathrm{T}$ cells expressing activation markers that were, nevertheless, hyporesponsive to cognate self antigen/MHC complexes. The implications were that $\mathrm{T}$ cell self-reactivity to a ubiquitous systemic antigen was sufficient to initiate a cascade of events, leading to a chronic inflammatory arthritis. To probe in depth the molecular nature of the effector response that leads to arthritis, focussing on the role of $\mathrm{B}$ cells as potential antigen presenting cells (APCs), as a source of antigen or as producers of pathogenic autoantibodies.

\section{Significant findings}

Firstly, adoptive transfer of splenocytes from healthy KRN TCR transgenic mice (B, or B x N) into IAg7 positive or negative, RAG1 or TCR apha deficient recipients, revealed that T cells, B cells and I$\mathrm{Ag} 7$ expression were essential for arthritis development. When the effector phase was evaluated using arthritic mice as donors, I-Ag7 expression on recipient APCs was not essential, as long as an I-Ag7 
restricted T/B cell interaction had occurred previously. A definitive role for this T/B cell cognate interaction was suggested by the results of two experiments. Firstly, when the Ig repertoire of B cells was progressively contracted by introducing rearranged "knock-in" VHDHJH and/or VKJK segments into the germline, arthritis onset was substantially delayed and disease severity was attenuated. Disease was completely prevented in mice homozygous for the "knocked-in" alleles at both IgH and IgK loci. This also indicated that Ig specificity was important for disease. Secondly, arthritis development could be prevented in adoptive transfer experiments when recipient B cells were CD40 deficient. That KRN transgenic T cells expressed CD44hi, CD62lo, CD45RBlo in vivo in the absence of B cells, indicated that the putative antigen was not $\mathrm{B}$ cell derived, nor uniquely processed or presented by B cells; and that $\mathrm{T}$ cells could be primed in the absence of B cells. Nevertheless, the effector component did originate from B cells, since multiple injections of as little as $100 \mathrm{ul} \mathrm{serum,} \mathrm{or} \mathrm{IgG} \mathrm{purified} \mathrm{from} \mathrm{serum} \mathrm{of} \mathrm{arthritic}$ mice could induce chronic inflammatory arthritis in B cell-deficient recipients within two days of injection, with all the histological features of arthritis observed in $\mathrm{K} / \mathrm{B} \times \mathrm{N}$ mice. The purified IgG fraction contained no rheumatoid factor activity, and minimal anti-collagen II reactivity. These serum transfer experiments indicated that KRN T cells still had effector function

during the later phase of disease.

\section{Comments}

This is outstanding work, and in my opinion contributes more to our understanding of the mechanisms of autoimmune arthritis, than mouse models reported to date. Hard-core immunologists are strongly urged to read the finer details of the transfer models for real pleasure. The Mathis and Benoist laboratory can now address the following questions. What is the antigenic specificity of the TCR and Ig responses? Is it a ubiquitous systemic antigen or a joint specific antigen that drives the disease process? Are endogenous non-transgenic TCR, also expressed on T cells from KRN mice, involved in the disease process? What is it about I-Ag7 that contributes to disease? And perhaps the toughest of all - why does this self-reactivity target the joint? The answers to these questions are eagerly awaited, but knowing this laboratory, we shouldn't have to wait too long for the answers.

\section{Methods}

The nomenclature used for mice in this paper is as follows: $\mathrm{K}$ - KRN TCR transgene; B - C57B1/6; K/ $\mathrm{B}$ - KRN TCR transgene on the C57Bl/6 background; K/B x N - KRN TCR transgene on the C57Bl/6 background crossed to NOD F1 hybrid; B x N - C57Bl/6 x NOD F1 hybrid. The experimental strategy was based on an adoptive transfer system which induces arthritis within six to seven days of cell transfer. Splenocytes from healthy or arthritic KRN donors, T/B cell depleted splenocytes or purified subsets of $\mathrm{T}$ and/or B cells were transferred to B, or B $x$ N unmanipulated mice, or recipients which lack alpha beta T cells (TCR alpha deficient) or both T and B cells (RAG1 deficient). The role of the immunoglobulin (Ig) repertoire and CD40 ligand /CD40 interactions was studied using mice with rearranged VHDHJH and/or VKJK segments "knocked-in" to the germline, and CD40 knockout mice, 
respectively. Passive transfer of disease was achieved with repeated injections of serum, or a purified $\mathrm{IgG}$ fraction from pooled sera of arthritic mice.

\section{Additional information}

The original KRN TCR transgenic mouse was reported in the following paper:

Kouskoff V, Korganow AS, Duchatelle V, Degott C, Benoist C, Mathis D: Organ-specific disease provoked by systemic autoimmunity.

Cell 1996, 87:811-822 (Abstract).

\section{References}

1. Korganow AS, Ji H Mangialaio S, Duchatelle V, Pelanda R, Martin T, Degott C, Kikutani H, Rajewsky K, Pasquali JL, Benoist C, Mathis D: From systemic T cell self-reactivity to organ-specific autoimmune disease via immunoglobulins. Immunity. 1999, 10: 451-461.

This PDF file was created after publication. 